\title{
Sartre'ın Varoluşçu Felsefesi ve Dava Edebiyatı Teorisi
}

\section{Sartre's Existentialist Philosophy and Theory of Committed Literature}

\author{
Metin $\mathrm{Bal}^{1}$
}

'Doç. Dr., Dokuz Eylül Üniversitesi, Edebiyat Fakültesi, Felsefe Bölümü, İzmir, Türkiye

ORCID: M.B. 0000-0003-3448-3736

\author{
Sorumlu yazar/Corresponding author: \\ Metin Bal, \\ Dokuz Eylül Üniversitesi, Edebiyat Fakültesi, \\ Felsefe Bölümü, Tınaztepe Yerleşkesi, Öğretim \\ Üyeleri Binası, 3. Kat, Oda no: 328, PK: 35370 , \\ Buca, İzmir, Türkiye \\ E-mail/E-posta: balmetin@gmail.com \\ Başvuru/Submitted: 01.05.2019 \\ Revizyon Talebi/Revision Requested: \\ 07.05.2019 \\ Son Revizyon/Last Revision Received: \\ 12.05.2019 \\ Kabul/Accepted: 19.05 .2019

\section{Atıf/Citation:} \\ Bal, Metin. "Sartre'ın Varoluşçu Felsefesi ve \\ Dava Edebiyatı Teorisi." Felsefe Arkivi 50 (2019): \\ 17-29. \\ https://doi.org/10.26650/arcp2019-589759
}

\section{ÖZET}

Bu makale Jean-Paul Sartre'ın varoluş̧̧u felsefesi ve sanat teorisi üzerinedir. Sartre önce fenomenolojik ontolojiyi, ardından hümanist ateist varoluşçuluğu kurar. Sartre sanat felsefesi alanına katkısı olan dava edebiyatı teorisini fenomenolojik ontoloji ve hümanist ateist varoluş̧̧uluk zemininde tasarlar. Makalenin ilk bölümünde Sartre'ın düşüncelerinin kaynakları ve temelleri kısaca açıklanır. Ikinci bölümde dava edebiyatı teorisi açıklanır. Burada, Sartre'ın sanat teorisinin en önemli özelliği, başka bir deyişle, Sartre'ın düzyazı sanatı olan edebiyatı plastik sanatlardan ayırması açıklanmaya çalışılır. İkinci bölüm dört ayrı alt başlıktan oluşur. İkinci bölümünün ilk kısmında Sartre'ın estetik saflık teorisine karşı eleştirisi incelenir. İkinci kısımda sanatın gelişimi ve insan özgürlüğü arasında bir bağ kurulur. Üçüncü kısımda edebiyat sanatının plastik sanatlardan farkı belirlenir. Dördüncü ve son kısımda dava edebiyatının anlamı tanımlanır.

Anahtar Kelimeler: Sartre, fenomenolojik ontoloji, hümanist ateist varoluşçuluk, dava edebiyatı teorisi

\section{ABSTRACT}

This article is on Jean-Paul Sartre's existentialist philosophy and his theory of art. Sartre, first of all, sets up phenomenological ontology, then founds humanist atheist existentialism. Sartre projects his theory of committed literature as his contribution to the field of philosophy of art on phenomenological ontology and humanist atheist existentialism. In the first part of this article, a brief description of the sources and grounds of Sartre's ideas are given. In the second part, the theory of committed literature is explained. Here, the most important property of Sartre's art theory, namely Sartre's separation of literature from plastic arts is clarified. The second part of the article is composed of four sections. In the first section of the second part, Sartre's critique against the theory of aesthetic purity is investigated. In the second section, a relation between development of art and human freedom is set up. In the third section the difference between art of literature and plastic arts is determined. In the fourth and the last section the meaning of committed literature is defined.

Keywords: Sartre, phenomenological ontology, humanist atheist existentialism, theory of committed literature 


\section{Giriş}

Bu yazıyı Leonardo da Vinci'nin doğum gününe ithaf edilen 15 Nisan 2019 Dünya Sanat Günü (World Art Day) kutlamasına bir armağan olarak kaleme alıyorum. Uluslararası Dünya Sanat Kurumu (International Association of Art) tarafından ilki 2012'de kutlanan Dünya Sanat Günü’nün amacı, "yaratıcı etkinlik" hakkında dünya çapında bir farkındalık oluşturmaktır. Uluslararası Dünya Sanat Kurumu’nun 2012'de Meksika’da düzenlediği Genel Kurul Toplantısı'nda sanat hakkında şöyle bir not düşüldü: "Dünyanın bugün yaşadığı kargaşa, düşünce ve ifade özgürlüklerinin bu çalkantılı dünyaya getirebileceği güce ihtiyaç duymaktadır. Bu çabayı, bu dünyanın sanatçılarından daha fazla kim göstermektedir?”" İşte bunun önemini, felsefesi baştan sona "özgürlük araştırması"ndan oluşan Jean-Paul Sartre’ın yapıtlarına² bakarak anlamayı deneyebiliriz.

Bir sanatçı filozof olan Sartre'ın felsefesinin amacı, varoluşu, başka bir deyişle - Heidegger'in Varlık ve Zaman (1927) yapıtında yaptığı tanıma dayanarak söyleyecek olursak ${ }^{3}$ - bir varolan olarak insan demek olan Dasein'ın varlıkla bağını, burada ve şimdi olan canlı bireysel insanı anlamamızı sağlamaktır. Sartre bu amacını "fenomenolojik ontoloji” "yi, "ateist humanist varoluşçuluğu” ve sorumluluk, dava ya da bağlı edebiyat teorisini kurarak gerçekleştirmeye çalışır. "Sanat sanat içindir" mottosunda özetlenen estetikte saflığı amaçlayan soyut sanat teorisine karşı Sartre yeni bir imge anlayışı geliştirir ve buradan hareketle düzyazı olan edebiyatı, özel olarak, plastik sanat kategorisine yerleştirdiği şiirden, genel olarak ise plastik sanatlar kategorisinden ayırır.

\section{BÖLÜM: Sartre’ın Düşüncelerinin Kaynakları}

Sartre’ın düşünce çabalarının özeti, daha 1938'de yazdığı Bulantı romanından başlayıp bu yazıda ayrıntılı olarak üzerinde durduğum, bu yazı için önemli gördüğüm son teorik yapıtı Edebiyat Nedir? e (1947) kadar, tek cümleyle: Özgürlük "insanın varlığıdır." ve "özgürlüğün özü yoktur.”

1 "Celebrating art and creativity on world Art Day." Erişim 05 Nisan 2019. https://sciencelens.co.nz/2013/04/15/ world-art-day/

2 Düşünsel gelişimi içinde Sartre’ın yapıtları: Benliğin Aşkınlı̆̆ı ve İmgelemin Psikolojisi ve İmgelem. İmgelemin Psikolojik Bir Eleştirisi (1936), Bulantı (1938), Bir Duygular Kuramı İçin Taslak (1939), Duvar (1939), Varlık ve Hiçlik (1943) Bu yapıtında fenomenolojik ontolojiyi geliştirir. Gizli Oturum (ya da Çıkış Yok) (1944), Özgürlük Yolları roman üçlemesi: Akıl Çă̆ı (1945), Yaşanmayan Zaman (1947), Yıkılış (1949), Varoluş̧uluk Bir Hümanizmdir (1946). Bu yapıtında humanist ateist bir varoluşçuluk teorisi geliştirir. Edebiyat Nedir? (1947). Fenomenolojik ontolojik humanist ateist varolușçu bağlı/sorumlu sanat anlayışını bu yapıtında geliştirir. Şeytan ve Yüce Tanrı (1951), Saint Genet: Komedyen ve Şehit (1960), Estetik Üzerine Denemeler (1963), Sözcükler (1963) 1964'te Nobel Edebiyat Ödülü’ne layık görülür. Yöntem İçin Araştırma (1960), Diyalektik Aklın Eleştirisìnin (Cilt I. 1960) “Giriş”'idir. Cilt. II. (1985), Aile Budalası (1971-2) (Beş kitaptan oluşur fakat Fransızca’da 3 cilt halinde yayınlanmıştır.) Aile Budalası yapıtı İmgesel, İmgelem Hakkında Fenomenolojik Bir Psikoloji (1940) kitabının ve Yöntem Sorusu (1957, Questions de Méthode) denemesinin devamı olarak düşünülebilir. Jameson, Sartre, Origins of Style (1961)

3 “Dasein'ın şu veya bu tutum içinde olduğu, öyle ya da böyle her daim belirli bir tutum gösterdiği varlığına varoluş diyoruz.” Martin Heidegger, Varlık ve Zaman. Çeviren Kaan Ökten. (İstanbul: ALFA, 2018). 34 . \$4

4 Sartre, Jean-Paul. Varlık ve Hiçlik. Çeviren Turhan Ilgaz ve Gaye Çankaya Eksen. (İstanbul: İthaki, 2010). 38.

5 Jean-Paul Sartre, Existentialism and Humanism. Translation and introduction by Philip Mairet. (London: Methuen \& Co. LTD., 1966). 55.

6 Jean-Paul Sartre, Being and Nothingness, An essay on phenomenological ontology. Translated by Hazel E. Barnes. Intdoduction by Mary Warnock, with a new preface by Richard Eyre. (London and New York: Routledge, 2003). 463.

7 Sartre, Being and Nothingness, 460. 
Bulantı romanın kahramanı Antoine Roquentin'in düşüncesiyle ifade edecek olursak: "Varolmayı sürdürmek için hiçbir neden yok" ("No reason for existing”) Roquentin başka bir yerde bu düşünceyi farklı cümlelerle şöyle ifade ediyor: "Burada bulunmamız için tek bir neden yoktu. [...] Her var olan, ötekilerin karşısında kendini fazlalık olarak hissediyordu. Fazlalık.” İnsan varoluşu hiçbir nedene ya da öze dayandırılamayacağı için, bu haliyle insan diğer varolanlar arasında bir fazlalıktır. Sartre daha sonra yazdığı ana yapıtı Varlık ve Hiçlik’te (1943) özgürlük konusundaki düşüncelerininin formülasyonunu şöyle yapar: "[Özgürlükte] varoluş özü önceler ve ona komuta eder." ${ }^{10}$ Sartre bu konuda açıklama yaptığı daha sonraki yazısı olan Varoluş̧uluk ve Hümanizm'de (1946) insan özgürlüğü hakkındaki düşüncesinin zirvesine varır: "Varoluş özden önce gelir."11

Varoluşçuluk felsefe tarihinde modernizm döneminde ortaya çıkan derinlik modellerinden biridir. Fenomenolojik ontolojiye, hümanist ateist varoluşçuluğa ve dava edebiyatı teorisine varan Sartre’ın düşüncelerinin kaynaklarına ve onlardan hangi bakımdan yararlandığına bakacak olursak şöyle bir sıralama yapabiliriz: Modernizmin ilk filozofları Arthur Schopenhauer (hayatın anlamı sorusu) ve Friedrich Nietzsche (anti-nihilizm ve anti-realizm). Søren Kierkegaard (Bireyin dünyadaki hiçbir şeyle gerçek bir bağının olmaması), Edmund Husserl (fenomenoloji), Karl Marx - Friedrich Engels (eylem ve tarih bilinci), Karl Jaspers ("varoluş felsefesi” terimi) ve Martin Heidegger (varlık ve hiçlik sorusu, Fundamental ontoloji, hermeneutik fenomenoloji, sibernetik füturoloji, metafiziğin onto-teolojik inşasının eleştirisi).

Sartre, yirminci yüzyılda, George Lukács ve Frankfurt Okulu düşünürleri yanında düşünce dünyasında irrasyonalizmin yükselişine karşı direnen tarafta yer alır. Sartre’ın irrasyonalizmi hedef almasının nedeni, "mauvaise foi" 12 adını verdiği, insanın kendi kendini kandırmasının ya da "kötü inanc" ının nedenlerini göstererek, onu kendi özgürlüğüyle karşı karşıya bırakmaktır. Schopenhauer ve Nietzsche'den başlayarak modernist düşünürlerin büyük kısmı "yaşam felsefesi” adına "bilinç felsefesi” nden vazgeçerken, Sartre "bilinc”e özellikle vurgu yaparak düşüncenin rasyonel boyutunu tekrar inşa eder. Sartre Varlık ve Hiçlik yapıtında geliştirdiği fenomenolojik ontoloji yöntemi yoluyla "bilinç felsefesi” nin "yaşam felsefesi”yle bir araya getirilebileceğinin bir kanıtını sunar.

Sartre’ın en temel esin kaynağı Husserl'dir. Husserl'in kurduğu fenomenoloji disiplininden Sartre üç önemli şey öğrenir. İlki, "bilinc” in ne demek olduğu. İkincisi, Husserl'in aynı zamanda "a priori ya da saf psikoloji” ${ }^{33}$ adını verdiği fenomenolojinin psişik yaşamla ilgili geliştirdiği doğru, başka bir deyişle bilimsel anlayış. Üçüncüsü ise daha önceleri görünüşe yüklenen saf olumsuzluk anlamını sona erdirmesi ve görünüşe "tam olumluluk" ${ }^{14}$ anlamı kazandırması, kısaca, Nietzsche’nin sözleriyle "ard-dünyalar-yanılsaması" ${ }^{15}$ nın sonlandırılmasıdır.

8 Jean-Paul Sartre, Nausea. Translated by Robert Baldick. (London: Penguin, 1965). 162.

9 Jean-Paul Sartre, Bulantı. Çeviren Selâhattin Hilâv. (İstanbul: Can Yayınları, 2009). 174.

10 Sartre, Varlık ve Hiçlik, 556.

11 Sartre, Existentialism and Humanism, 26.

12 İng. bad faith, self-deception, kendini aldatma. Sartre, Varlık ve Hiçlik, 97. / Sartre, Being and Nothingness, 68.

13 Edmund Husserl, "Fenomenoloji", çeviren Aydın Gelmez. (Baykuş, Felsefe Yazıları Dergisi, 6 (2010): 29-47). 29.

14 Sartre, Being and Nothingness, 2.

15 Sartre, Varlık ve Hiçlik, 20. 
Sartre'ın kurduğu fenomenolojik ontoloji teorisinin en dikkate değer düşüncesi varolanlar alanını üçe ayırmasıdır. Varolanın bu üç alanı, kendinde ya da kendi-içinde-varolan, kendi-içinvarolan ve öteki-için-varolandır. Kendinde-varolanın temel özelliği nedensellikle belirlenmesi ve edilgen olmasıdır. Kendi-için-varolanın özelliği olumsuzluğun söz konusu olması ve özgür olmasıdır. Sartre burada, bilinci kendinde-varolandan ve öteki-için-varolandan ayırarak "kendiiçin-varolan" bir şey olarak tanımlar. "Bilinç kendi-için-varolandır, çünkü bilinç kendi kendinin nedenidir." ${ }^{16}$ İnsan da bilinçli bir varolan olarak kendi-için-varolandır çünkü bilincin olduğu gibi insanın da varolmasının dayandırılabileceği hiçbir öz ya da neden yoktur. Bu düşünce, insanın bir doğasının olmadığı anlamına gelir. İnsanın bir doğası yoktur fakat "bir insan durumu evrenselliği” ${ }^{17}$ ya da bir durumun insan dünyasındaki evrenselliği söz konusudur. Kısacası, bir insan doğası yerine bir insan durumu vardır. Varoluşun absürdlüğü işte buradan kaynaklanır, çünkü insan varolmak zorunda değildir. İnsan ancak böylece özgürdür. Öteki-için-varolan durumunun ne anlama geldiğiyle ilgili bakılabilecek en etkili yapıt Sartre'ın Varlık ve Hiçlik’ten bir yıl sonra yazdığ $C_{1} \imath$ Łış Yok (ya da Gizli Oturum) (1944) adlı tiyatro oyunudur. Çıkı̧̧ Yok oyununda, ölmüş olduklarını ve cehenneme gönderildiklerini bilen üç insan bir odaya girer. Onlar burada, kendilerine acı vererek cezalandıracak hiçbir araç göremezler. İnsana acı verecek olan şeyi Garcin’in şu repliği ifade eder: "Cehennem - öteki kişilerdir." 18

Sartre insan varoluşunun özgür olduğu düşüncesini “eylem”e dayandırır. İnsanın özgür bir varolan olmasının kanıtı "eylem"dir, çünkü "eylem bir olanaklar çokluğunun var olduğunu"19 gösterir ve bir kimse bu eylemler çokluğundan birini yapmayı seçer. Bir kimsenin her durumda bir seçim ve kararla karşı karşıya kalması kaçınılmazdır. Eylemde bulunmak "dünyanın biçimini iyileştirecek şekilde değiştirmek" ${ }^{20}$ tir. İnsan böylece "bir girişimler dizisinden başka bir şey değildir." 21 Bunun sonucu olarak Sartre kendi varoluşçuluğunu "bir eylem ve öz-girişim ya da dava etiği” 22 olarak tanımlar. Eylemlerin değeri, onların seçilmiş olmasından gelir. Eylem yoluyla bir değer üretiriz. Sartre’ın karşı çıktığı realizmin ya da gerçekçiliğin yanılgısı, gerçeğin seyretmekle ortaya çıkacağını ve bunun sonucu olarak da, "yansız bir betimleme yapılabileceğini sanmak"23 olmuştur. Buna karşı insanın yaratıcı eylem gücünü cesaretlendiren Sartre şöyle diyor: "Bir anlam ifade eden şey insan tavrıdır." 24 İnsanın özgür olduğunu, onun psişik yönüne bakarak nasıl deneyimlediğini anlayabiliriz. Psişik bakımdan bu özgürlük kaygı, ya da Sartre’ın terimleriyle söyleyecek olursak "iç daralmas»" 25 ya da "elem" duygu durumu olarak deneyimlenir. "Ebediyen

16 Sartre, Varlık ve Hiçlik, 42.

17 "A human universality of condition." Sartre, Existentialism and Humanism, 46.

18 Jean-Paul Sartre, No Exit, and Three Plays. "No Exit", "The Flies." Translated by S. Gilbert. "Dirty Hands", "The Respectful Prostitute.” Translated by I. Abel. (New York: Vintage International Edition, 1989). 45.

19 Sartre, Existentialism and Humanism, 32.

20 Sartre, Being and Nothingness, 455.

21 Sartre, Existentialism and Humanism, 42.

22 "Ethic of action and self-commitment." Sartre, Existentialism and Humanism, 44.

23 Jean-Paul Sartre, Edebiyat Nedir? Çeviren Bertan Onaran. (İstanbul: Can Yayınları, 2008). 71.

24 Sartre, Varlık ve Hiçlik, 51.

25 İng. anguish, elem, keder. Alm. die Angst, die Pein, die Qual, die Seelenqual, seelischer Schmerz. Sartre, Varlık ve Hiçlik, 66 . 
özümün ötesinde, edimimin nedenleri ve güdülerinin ötesinde varolmaya mahkumum. Kısacası ben özgürlüğe mahkumum. [...] Özgür olmaya son verme özgürlüğümüz yoktur.” ${ }^{26} \mathrm{O}$ halde soralım: Neden kendimizi bir gerçeğe mahkum tutuyoruz? Neden bir gerçekten ayrılamıyoruz? Ya da neden realistiz ve öteki kimseleri de bu gerçeğe davet ediyoruz? Bir kimsenin "gerçeklik durumunun dışına çıkacak olanağı fark edememesi, başka bir deyişle, kendinde-varolan olarak yaşamını sürdürmesinin nedeni, onun bu düzene "alışmış” olması değil, "başka türlü olabileceğini hayal bile edememesidir.” ${ }^{27} \mathrm{Bu}$ inanç ise özgürlüğün reddi anlamına gelir. Özgürlüğün reddi, bir kimsenin kendisini kendi-için varolan olarak değil kendinde-varolan olarak tanımak istemesidir. Sartre buna "kötü inanç", öz-aldanma, "kendi kendini aldatma" ya da "kendini kandırma"28 der. Bir kimsenin kendisini özgür bir varolan olarak tanıyıp tanımadığını, o kimsenin yaptığı şeyi kendisine dayanarak yapıp yapmadığına dikkat ederek bilebiliriz. Bir kimseyi kendisini aldatmaktan hiçbir şey alıkoyamaz. Kısacası işaretleri yorumlamakta özgürüz. Sartre’ın Şeytan ve Yüce Tanr (1951) oyunundaki karakterler olan Nasty, Goetz ya da Karl'ın yaptıkları gibi ${ }^{29}$ bir kimse peygamber olduğunu iddia edebilir ya da iyi bir okuyucu olduğunu düşünebilir. Bu kimseyi, neyi seçeceği konusunda hiçbir şey zorlayamaz.

\section{BÖLÜM: Sartre’ın Sanat Felsefesine Katkısı: Dava Edebiyatı Teorisi}

"Bu yüzyılın başında ortaya çıkan dil hakkındaki kriz poetik bir krizdir." 30

Sartre'ın sanat felsefesine katkısını anlamak için onun dava edebiyatı teorisini kurana kadar geliştirdiği düşüncenin farkında olmalıyız. Bu nedenle buraya kadarki bölüm bir hazırlıktı. Şimdi asıl konuya girebiliriz. Sartre’ın sanata en önemli katkısı sorumlu ya da bağlı edebiyat, başka bir deyişle, dava edebiyatı teorisini kurmuş olmasıdır. Sartre için sanatsal etkinlik yaratıcıdır, çünkü bir sanat yapıtı "varlığın bütünlüğünün yeniden ele geçirilişidir." ${ }^{31}$ Bir sanatçı ortaya koyduğu sanat yapıtıyla "dünyanın bütünlüklü bir yenilenmesini amaçlar."32

\subsection{Sartre'ın Estetik Saflık Görüşüne Karşı Eleştirisi}

Sartre’a göre, sanatın değer yitiminin kaynağı realist tutumdur. Realist sanat anlayışı düşünce tarihinde Platon'un kurduğu sanat teorisidir. Dolayısıyla Sartre anti-realist, anti-Platoncudur. Platon ideayı, formu ya da imgeyi nesneden ayrı, kendi başına bir varolan olarak düşünür. Böylece imgeyi zihinden ya da bilinçten ayrı, kendi başına varolan bir şey olarak düşünme yanılgısı Platon’a

26 Sartre, Being and Nothingness, 461-462.

27 Sartre, Varlık ve Hiçlik, 553./ Sartre, Being and Nothingness, 456.

28 Jean-Paul Sartre, Being and Nothingness, A Phenomenological Essay on Ontology. Translation and introduction by Hazel E. Barnes. (New York: Washington Square Press, 1992). 580.

29 Jean-Paul Satre, Toplu Oyunlar, Gizli Oturum, Mezarsız Ölüler, Sinekler, Kirli Eller, Şeytan ve Yüce Tanr, Saygzlı Yosma. Çeviren Işık M. Noyan. (İstanbul: İthaki Yayınları, 2009a). 468, 604, 633.

30 Jean-Paul Sartre, What is Literature? Translated by Bernard Frechman, with an introduction by David Caute. (London and New York: Routledge, 2001). 8.

31 Sartre, Edebiyat Nedir?, 67.

32 Sartre, What is Literature?, 42. 
kadar geri götürülebilir. Philosophia perennis içinde tartışma oluşturan bu görüşe "realizm" ya da "kavram gerçekçiliği” diyoruz. Realizme göre imge, imge olarak tasarımladığı, tekabül ettiği ya da Platon'un Bölünmüş Çizgi Analojisi33'nde açıkladığı gibi, öykündüğü şeye göre metafizik değer hiyerarşisinde hakikat değerinden yoksun, daha aşağı bir dünyada bulunur. Platon'un ideler dünyasında düşünen bir şey ya da bilinç yoktur. Bu nedenle Sartre kendi sanat teorisini kurmaya "imge” sorunundan başlıyor. Sartre düşünce tarihinde imge görüşlerine baktığında imge ve düşünce arasında, psikolojik bakımdan gerçek bir boşluğun ya da uçurumun olduğunu farkeder. Sartre’a göre en başta imge ve bilinci ayrı düşününce, bu ikisi arasında rasyonel bir geçiş yapmak mümkün olmaz. Sanat felsefesi bağlamında imge ve nesneyi ayrı düşünen tutuma Sartre "estetik saflık" ("aesthetic purism”34) adını verir.

Estetik saflığın yanılgısı, imgeyi kendi başına varolan bir şey olarak düşünmesidir. Nesne ve ona ait imge arasındaki bağlantı kopukluğunun estetik deneyim için çok önemli olumsuz bir sonucu vardır, çünkü estetik saflık tutumu, insanı yalnızca "seyir" eylemiyle sınırlandırır. Realistler ya da rasyonalistler gibi imgeyi bilinçten ayırdığımızda ya da emprisistler gibi bilincin kendisini psikolojik sürecin bir ürünü haline getirdiğimizde sanatçııı yalnızca bir kaşif, estetik deneyimi yaşayan kimseyi ise bir izleyici kılmış oluruz. Estetik deneyimi, yalnızca keşfetmeye ve izleyiciliğe indirgenmiş kimseler, gerçek saydıkları şeye asla ulaşamamışlardır. Dünyevi olanı değerden düşürmek, inanç sözcülerinde saptayabileceğimiz nefrofili hastalarının ya da örneğin Platon gibi realistlerde saptayabileceğimiz paramnesia hastalarının bir tutumudur. Sartre’a göre güzellik değeri, kendinde ya da kendi-içinde-varolan bir şeye yüklenemez: "Güzellik yalnızca imgesel olana yüklenebilen bir değerdir. Güzellik dünyanın kendi özünde olumsuzlanması anlamına gelir.” ${ }^{35}$ Gerçek olduğu söylenerek dayatılan şeyi olumsuzlamanın aktörü olarak sanatı öne süren Sartre buradan hareketle, "sanat yapıtı bir irrealitedir." ${ }^{36}$ diyor. Sanatçı gerçekle uğraşmaz ya da sanatçı gerçeğin peşinde değildir, onun şimdiden ortaya koyduğu şey gerçektir ve hakikat değeri kendi içindedir. Realizmin ya da estetikte safçılığın sanat anlayışı estetik deneyimde bilincin, onun dışındaki gerçek sayılan şeye öykünmesi ile sınırlandığı için, buna tasarımlamacı sanat anlayışı diyoruz. Sartre buna karşı tasarımlamacı olmayan ya da anti-tasarımlamacı diyebileceğimiz bir sanat anlayışını geliştirir. Tasarımlamacı olmayan sanatçı ve sanat yapıtlarına Sartre'dan önce Heidegger değinmişti. Heidegger’e göre, örneğin Hölderlin, Rilke, Cézanne, Klee, Zen Sanatı, Japon Noh Tiyatrosu tasarımlamacı olmayan sanatçı ve sanat türleridir.

Anti-tasarımlamacı sanat anlayışına göre, sanat yapıtı imgenin gerçekleşmesi değil, Sartre’ın "analogon” adını verdiği şeyin sergilenmesidir. Sanatçının görevi zihinsel bir imgeyi gerçekleştirmek değil, izleyicinin imgeyi kavrayabilmesi için maddi bir analogon sergilemektir. "Ne imgesel

33 Platon Devlet yapıtının "Altıncı Kitabı”nda yer alan Bölünmüş Çizgi Analojisi (507 b - 511e Paragraflarında) kısmında görünüşler dünyası ve düşünülür dünya ya da ideler dünyası arasındaki ayırımını açıklar. Bkz. Platon, Devlet. Çeviren Sabahattin Eyüboğlu ve M. Ali Cimcoz. (İstanbul: Remzi Kitabevi, 1988). 194-198.

34 Sartre, What is Literature?, 17.

35 Jean-Paul Sartre, The Psychology of Imagination. Translated by Bernard Frechtman. (New York: Philosophical Library, 1948). 281.

36 Jean-Paul Sartre, The Imaginary, A Phenomenological Psychology of the Imagination, with introduction by Arlette Eelkaim-Sartre and Jonathan Webber. (London: Routledge, 2010a). 188. 
olanın gerçekleşmesi diye bir şey vardır, ne de bir kimse bu imgesel olanın nesneleşmesinden söz edebilir." ${ }^{37}$ Sartre bu düşüncesiyle, mimetik, başka bir deyişle öykünmeci sanat anlayışına son verir. Böylece sanat yapıtı bir tasarımlama değil, başka bir gerçekliktir ya da irrealizasyondur. Örneğin bir resim tablosunda resmedilmiş dünyanın ardında gerçek sayılabilecek başka bir dünya yoktur. Macbeth'i oynayan oyuncu bir analogondur. Bu oyuncu, oyunu bu şekilde irrealize eder, başka bir deyişle başka bir gerçek yaratır.

\subsection{Sanatın Gelişimi ve İnsan Özgürlüğ̈̈i Arasındaki Bağ}

Sanatın gelişiminin insanın özgürleşme tarihiyle bir bağı vardır. Bunu görmek için şimdi tarihsel olarak biraz geriye doğru gidelim. 16. yüzyılda düzyazı ve plastik sanatlar henüz aynı sanat kategorisi altında sınıflandırılıyordu. Örneğin Sistine Şapeli freskleri (1508-1512) çalışmasında görüldüğü gibi "Michelangelo (1475-1564) Plastik sanatları "konuşturacak bir dil yaratmayı [...] araştırır durur. Sistine Şapeli'nin tavanına resmin diliyle oluşturduğu fresklerle bir kitap yazar." ${ }^{38}$ Şimdi de aynı dönemden çok farklı bir sanatçıya bakalım: Jacobo Robusti Tintoretto (1518-1594) Rönesans döneminde sanat zanaattan ayrılmamış fakat dinden ayrılmaya başlamıştı. Sanatın dinden ayrılması olayında önemli bir yeri olan Tintoretto' nun gerçekleştirdiği şeyi, felsefi olarak şöyle betimleyebiliriz: Plastik sanatın yazıdan ayrılışı ya da ideal olandan dünyevi olana geçiş. Bunu anlamak için rönesansın sanat yapıtlarından önce dinin egemenliğinde olan sanatın nasıl olduğuna kısaca bakalım. Soralım: Ortaçağda sanat yapıtının durumu neydi? Gotik sanatçı Villard de Honnecourt'un (1200-1250) eskiz defterinde çizdiği Aslan ve Kirpi (1225-35) adlı eskiz çalışması ve Yazgının Tekerleği (1230) adlı eskiz çalışmasında görüldüğü gibi Ortaçağın sanat yapıtında önce tuvale boş şema ya da iskele çizilir, sonra bu boş alan dünyevi içerikle doldurulur. Ortaçağ sanatçısının yaptığı şey "soyut bir çerçeveyi doğrudan gözlem üzerine dayanan detaylarla doldurmak" ${ }^{39}$ tır. Dünyevi olanın inanç sözcüleri tarafından, insanüstü ve kutsal olduğuna inanılan varlıklar adına yağmalanması söz konusudur.

Sanat evreninde insanın yeryüzü varlığı olduğu ilkin İtalya'da özellikle Floransa’da açıklanır. Sanat dünyasındaki bu gelişmenin öncü aktörü olan sanatçılara değinmek faydalı olacaktır. Floransalı Giotto di Bondone (1267-1337) ve Sienalı Duccio di Buoninsegna (1255-1319) kendi tablolarında derinlik ve hacim düşüncesini keşfetmeye başladılar. Doğrusal perspektivi sanat dünyasında yapıtlarında 1420'li yıllarda ilk kullanan Floransa'lı mimar Fillipo Brunelleshi'dir. (1377-1446) Brunelleshi'nin Floransa'daki Santo Spirito Kilisesi (1420) çiziminde görüldüğü gibi "doğrusal perspektiv sistem, derinlik yanılsamasını, tüm çizgilerin birbirlerine yaklaşarak göz hizasında, ufukta birleştikleri "gözden kaybolan noktalar" 1 kullanarak iki boyutlu bir düzlem üzerinde tasarımlar.” ${ }^{40}$ Bir diğer rönesans ressamı Masaccio (1401-1428) - Cennetten Kovuluş, Çocuğu ve Meleklerle Meryem Ana ve Hürmet resim tablolarında görüldüğ̈̈ gibi -perspektivin

37 Sartre, Varlık ve Hiçlik, 189.

38 Jean-Paul Sartre, Estetik Üstüne Denemeler. Çeviren Mehmet Yılmaz. (Ankara: Doruk Yayımcilık, 1999). 37.

39 H. W. Jonson, History of Art, Vol. I. Fourth Edition, revised and expanded by Anthony Janson. (New York: Abrams, 1991). 391.

40 “Op Art History Part I: A History of Perspective in Art.” Erişim 11.04.2019. http://www.op-art.co.uk/history/ perspective/. 
tüm özelliklerini yapıtlarında kapsamlı olarak kullanan ressamdır. Rönesans sanatı böylece, bu örneklerde görüldüğü gibi, teofaniden (Tanrı'nın görünümünden) orbisfaniye (dünyanın görünümüne) ve antropofaniye (insanın görünümüne) geçişi sağlar. Perspektivin kullanılmasıyla birlikte tuvalden duyuüstü dünya kovulur, böylece sanat yüzünü dünyaya yönlendirir: "Perspektif, kutsallığın bozulup dünyevileşmesi, hatta küfür derecesinde bir başkaldırıdır." ${ }^{11}$

Rönesans, sanat yapıtlarında, insan üstü varlıklardan vazgeçerek büyük uyanışı ya da dünyevi olanın dirilişini gerçekleştirir. Sanat ancak ilahi varlıklardan vazgeçtiğinde insanı kendi yalnızlığı ya da Sartre’ın terimiyle "terkedilmişliği”’ ${ }_{2}$ içinde kavrar. "Tanrı, insan ruhundan çıkarılıp firara zorlanmıştır. [...] Yaratmak için daha çok erken, yansıtmak için ise çok geçtir.” ${ }^{43}$ Dünyevi olana dönüş, insanın yeniden diriltilmesi ve kutsanması çabası demek olan rönesansın önemli bir katkısı da maniyerizmdir. Sartre’ın üzerinde ayrıntılı olarak durduğu Tintoretto geç rönesans sanatı olan maniyerizmin bir sanatçısıdır. "Maniera” Latince'de stil, tarz, üslup demektir. Rönesans dönemi, sanatçının zanaatçıdan ayrılıp yaratıcı olmaya, sanat yapıtının ise sparişten ve eşyadan ayrılıp hakikat değerini kendi içinde taşımaya başladığı sanat çă̆ıdır.

Tintoretto'nun tanınmasını sağlayan Aziz Markus’un Cesedinin Bulunuşu (1548) tablosu, çağdaşları tarafından dehşet verici bulundu. Bu tabloda kutsal olduğu düşünülen bir kimsenin cesedine sıradan bir insan muamelesi yapılır. Tintoretto' nun çalışmaları arasında Sartre'ın konuyla ilgili olarak önemsediği yapıt Venüs ve Marsın Vulkan Tarafindan Basılması (1551) tablosudur. Bu tablodaki konuyu daha önce Sandro Botticelli (1445-1510) Venüs ve Mars (1483) adlı yapıtında çalışmıştı. Botticelli bu yapıtında figürleri idealize eder. Üstelik resimdeki figürlerin bakışları birbirine dönük değildir. İnanç sözcülerinin öte dünyalarında perspektivin olmamasına paralel olarak, onların sanat yapıtlarındaki figürlerde “öteki” bulunmaz, çünkü inanç dünyasının insanı gözlerini dünyevi olana, insana değil vaad edilen gökyüzüne, öte dünyaya diker. Buna karşın Tintoretto resimlerindeki figürleri dünyevi bir olay etrafında birbirleriyle ilişkilendirir. Tintoretto'nun Venüs ve Marsin Vulkan Tarafindan Basılması tablosunda görüldügü gibi, o konuyu erotisize ederek dünyevileştirir. Rönesansın bu söylediğimiz özelliklerini Sartre olumlu karşılar. Fakat Sartre rönesans anlayışındaki "güzellik doğadadı»” görüşüne karşıdır, çünkü doğada kendiliğinden güzellik bulunmaz. Rönesans ard-dünyalar yanılsamasını kırarak, sanatı ait olduğu yerde, dünyada kavramıştır. Şimdi sıra güzelliği doğadan ayırmaktadır.

\subsection{Edebiyat ve Plastik Sanatlar Arasındaki Fark}

Sartre’ı dava edebiyatını kurmaya götüren yolun en belirgin aşaması düzyazıyı plastik sanatlardan ayırmasıdır. Sartre sanat türlerine özgü terimlerin dikkatsizce, rastgele kullanılmasından rahatsızlık duyar. "Aynı rahatlıkla dile gelebilecek tek bir sanat varmışçasına bugün müzik ya da yazın argosuyla "resimden söz etmek" ve ressam argosuyla da "yazından söz etmek” incelik sayılıyor.” ${ }^{44}$ Sanat türlerinin ortaya koyduğu yapıtların özellikleri arasındaki

41 Sartre, Estetik Üstüne Denemeler, 48.

42 Sartre, Existentialism and Humanism, 34.

43 Sartre, Estetik Üstüne Denemeler, 51.

44 Sartre, Edebiyat Nedir?, 13. 
farkı dikkatle inceleyen Sartre düzyazının bir plastik sanat türü olmadığını keşfeder. Bunun sonucunda, bir sanat türü olarak şiiri plastik sanatlar kategorisi altına yerleştirir. Edebiyat im, işaret ya da sözcükle şeye gönderme yapar, kısacası yazar bir şeyden söz eder, şiir ise, öteki plastik sanatların da yaptığı gibi, sanat yapıtıyla o şeyin kendisini ortaya koyar. Böylece bir plastik sanat türü olan şiirin sözleri şeylerden oluşur. Şairin dilindekiler "şey-sözcükler" ${ }^{35}$ dir. Örneğin Arthur Rimbaud'nun (1854-1891) şiirlerinde sözcükler şey-cümleye dönüşür. Rimbaud'nun bir dizesinden örnek verelim:

Ey mevsimler! Ey şatolar

Hangi ruhta yoktur kusurlar?

Rimbaud bu şiirdeki sorusuna cevap istiyor değildir. Cevap "sorunun ta kendisidir." ${ }^{4}$ Rimbaud okuyucudan bir cevap beklememektedir: "Bunu demek isteseydi, öyle söylerdi.” ${ }^{47}$

Edebiyatın plastik sanatlardan ayrı bir sanat türü olduğu görüşü modern sanat anlayışında da paylaşılır. Modern sanat felsefesinde sanat türlerinin ilk açık kategorizasyonunu Immanuel Kant (1724-1804) Yargı Yetisinin Eleştirisi (1790) adlı kitabında yapar. Fakat şiir, düzyazıyla birlikte Kant'ta hala aynı sanat kategorisi (Güzel Konuşma Sanatı) altında yer alır. ${ }^{48}$ Şimdi, plastik sanatların edebiyat sanatından farkını göstermek için şeyleri etkili bir şekilde ortaya koyan başka sanatçıların yapıtlarına da bakalım. Düzyazı yazarı sözcüklerle okuyucuya kılavuzluk eder fakat plastik sanatların sanatçısı yalnızca bir şey ortaya koyar. Örneğin Tintoretto Çarmıha Geriliş (1565) tablosunda gökyüzünü sarı renge boyamıştır. Sarı rengin ayrılık ve bunalım anlamına geldiğini biliyoruz. Burada gökyüzünün sarı renginin bir "bunalım”a işaret ettiği düşünülebilir. Fakat bu sarı gökyüzü, bunalıma işaret etmez. Gerçekte, bu sarı gökyüzü bir şey olarak bunalımı ortaya koyar. Sartre buna "şeyleşen bir bunalım." ${ }^{49}$ der.

Yüklenen anlam nesneyi delip geçer. Güller sadece duyum nesneleri değildir. Bakışı güllere çeviren sanatçı, yüklediği anlamla onları delip geçer. Sanatçı ilgilendiği nesneyi bambaşka bir şekilde yeniden yaratır. Örneğin bir müzik parçasındaki acı, bir şey olarak ortaya konulmuştur. Böylece müzik parçasında "acı var olmaz artık, vardır." ${ }^{50}$ Plastik sanat yapıtının, gösterdiği şeyi doğrulamak için izleyiciyi kendisi dışına göndermediğini ve bu bakımdan edebiyat yapıtından ayrıldığını göstermek için Sartre’ın, yapıtlarından örnek verdiği bir diğer sanatçı, yakın dostu olan heykeltraş ressam Alberto Giacometti'dir. (1901-1966) Giacometti bir sanatçı olarak öykünme yeteneğinden yoksun olduğu için modelle çalışma konusunda başarısızdır. Böylece

45 Sartre, Edebiyat Nedir?, 23.

46 Sartre, What is Literature?, 10.

47 Sartre, What is Literature?, 10.

48 1-) Güzel Konuşma Sanatı: a-) Güzel Konuşma (belagat) b-) Şiir 2-) Güzel Biçimlendirici Sanat: a-) Plastik Sanatlar: 1. Heykel, 2. Mimari. b-) Resim Sanatları: 1. Doğanın Güzel Betimlenmesi: Resim. 2. Doğa Ürünlerinin Düzenlenmesi: Bahçecilik. 3-) Duyumların Güzel Oyununun Sanatı: a-) Müzik, b-) Renk Sanatı. Bkz. Immanuel Kant, Yargı Yetisinin Eleştirisi/Kritik der Urteilskraft. Çeviren Aziz Yardımlı. (İstanbul: İdea Yayınevi, 2006). 192$199, \$ 51-\$ 52$.

49 "an anguish become thing." Sartre, What is Literature?, 3.

50 Sartre, Edebiyat Nedir?, 16. 
Giacometti sanat hayatının daha başında "gerçekçilikten kopar." ${ }^{11}$ Giacometti'ye göre varolanlar boşlukla çevrili ve boşlukla meydana gelirler. Kafes (1949-1950) bronz heykelinde görüldüğü gibi Giacometti şeyleri, boşluğu bir malzeme olarak kullanarak ortaya koyar. Giacometti’nin başka bir yapıtı olan Diego (1953) tablosunu izleyen bir kimse Diego'nun yaşama kavuştutulması ve varolması için neye ihtiyacı olduğunu bulmaya çalışır.

Sartre’ın yapıtlarını çözümlediği bir diğer sanatçı Robert Lapoujade'dır (1921-1993). Lapoujade sanat yapıtlarında varoluşun parçalanamaz birliğini gösteriyor. Lapoujade Aynalı Çift (Le couple au miroir) (1968) adlı çalışmasında insanı bir tek değil çift olarak ortaya koyar: "Bir çıplak ama, iki insanın varlığını taşıyan bir çıplak." ${ }^{52}$ Lapoujade varoluşun temel duygu durumu olan iç daralması ya da azabın resmini $\dot{I}_{\xi} k e n c e$ (1958) tablosunda ortaya koyar. Bu tablo işkencenin içimizde olduğunu "rezil benliğimizin en derin, en ücra noktalarına kadar, maalesef, ulaşmış" 53 olduğunu bize gösteriyor.

Sartre’ın ilgisini çeken bir diğer sanatçı Alexander Calder'dir. (1898-1976) Calder'in yapıtlaştıdığı şey “eylem”dir. Sartre’a göre Calder'in yapıtları “devinimli heykeller"dir. "Calder heykelde devinim yanılsamasından çok, devinimi gerçekten ele geçirir ve kullanır." ${ }^{4}$ Örneğin, esen bir rüzgar bu heykele çarparak ona hayat verir. Heykel böylece devinim kazanır. Calder'in İnsan (1967) adını verdiği heykel yapıtına bakan bir izleyici, orada devindirici güçlerin ortaya çıkardığı bir kimseyi deneyimler.

Plastik sanatların, şeyi doğrudan doğruya ortaya koymaları, onların hakikat değerinin kendi içlerinde olduklarını gösterir. Orada resmedilenler, şeyin kendisi olarak hakikattir. Böylece her bir sanat yapıtı kendi hakikatine sahiptir. Sartre’ın ne demek istediğini anlamak için birkaç sanat yapıtı örneğine bakalım. Vincent Van Gogh’un (1853-1890) Kadın Maden İş̧ileri (1882) tablosuna baktığımızda, burada, dondurucu kış ortasında mısır sapları gibi titreyen işçilerin bedenleriyle birlikte hakikatin de dondurulduğunu görüyoruz. Başka bir ressam olan Paul Klee'nin (18791940) Genç Proleteryan (1916) portresinde maden işçisinin yüzüyle birlikte hakikatin karartıldığını görürüz. Bir diğer ressam olan Francisco Goya’nın (1746-1828) 3 Mayzs (1814) tablosunda 1808'de Madridli yurtseverlerin idamını konu alan 3 Mayıs adlı resim tablosuna baktığımızda, orada, hakikatin kurşuna dizildiğini görüyoruz. Son olarak, ressam Pablo Picasso’nun (1881-1973) Guernica (1937) tablosuna baktığımızda İspanya'da düzenli ordunun Bask bölgesine saldırarak otomatik ağır silahlarla katlettiği halkla birlikte hakikatin paramparça edildiği görülmektedir.

\subsection{Sartre'ın Sanat Felsefesine Katkısı: Dava Edebiyatı Teorisi}

Sartre’ın sanat hakkındaki düşüncelerinde edebiyata özel bir önem vermesi bir tesadüf ya da keyfi bir tutum değildir. Bunun aksine Sartre modernizm döneminde düşüncenin ve sanatın merkezine bir konu olarak "insan” ın yerleşmiş olduğunu farkeder. İnsanların milyonlar halinde

51 Jean Genet, Giacometti’nin Atölyesi. Çeviren Hür Yumer. (İstanbul: Metis Yayınları, 2007). 79.

52 Sartre, Estetik Üstüne Denemeler, 121.

53 Sartre, Estetik Üstüne Denemeler, 123.

54 Sartre, Estetik Üstüne Denemeler, 125. 
birbirlerini katletmek için seferber olduğu Birinci Dünya ve İkinci Dünya Savaşları’nın da gösterdiği gibi felsefe bir tiyatro oyunu, "dram” haline gelir.

\footnotetext{
"Bugün mesele, insandır, hem etken, hem bir aktör olarak insan. [...] Bir tiyatro oyunu (Brecht'inki gibi destansı ya da dramsı) bugünün insanını sahnede göstermenin (yani düpedüz insanı göstermenin) en uygun yoludur. [...] Tiyatro felsefemsi ve felsefe de dramsıdır bugün." 55
}

Soralım: Nasıl oluyor da bir tiyatro oyunu onu izleyen kimseyi bir duygudan başka bir duyguya sürüklüyor? Ya da bir roman, onu okuyan kimseyi derinden sarsabiliyor? Bunun nedeni ona inanmak ya da ona bağlanmaktır. Sorumlu ya da "bağlanmış yazar, sözün bir eylem olduğunu ve ortaya koymanın değiştirmek anlamına geldiğini [...] bilir.” ${ }^{56}$ Bu sorumluluğun kaynağı, insanın karar vermek zorunda olmasıdır. İnsanın yarattığı, insanüstü olduğuna inanılan varlıkların da karar vermek zorunda olduklarını biliyoruz. Kutsal olduğu söylenen inanç sözcüsü kitaplara bakalım, göreceğiz ki Tanrı da insanlar arasında taraf tutuyor. "İnsanoğlu [...] Tanrı’nın bile karşısında yan tutmadan edemeyeceği bir yaratıktır.” ${ }^{57}$ Böylece sanatçı yazar sözcükleri rastgele kullanmaz, çünkü onlar yoluyla ilettiği düşüncelerden sorumludur. Sartre diyor ki: "[Yazar] sözcüklerin, [...] dolu tabancalar olduğunu bilir. Konuştuğu an, tetiğe basılmış demektir. Susmak da elindedir, ama ateş etmeyi seçtiğine göre, bunu [...] rasgele değil de, [...] hedef gözeterek yapması gerekir." ${ }^{58}$ Fakat Sartre’ın karşı çıktığı idealist yazarlar tüm zamanlar için geçerli olabilecek bir dil ararlar. Bu arayış boştur, dahası, bu bir sorumsuzluktur. Yazarın sorumluluğu, kendi zamanına ait olmasından kaynaklanır. Bir yazar sözcükleriyle, içinde bulunduğu yeni dünyayı ifade etmelidir. Bu şu anlama gelir: Yazar başka bir üslup geliştirir. Yazarın hangi üslubu seçeceği ya da geliştireceği önceden belirli değildir. "Biçim konusunda önceden söylenecek hiçbir şey yoktur." ${ }^{99}$ Saf, ölümsüz bir dil yaratmak isteyen idealist ve realist yazar ve düşünürler tarihten ve çağdaş olaylardan yalıtılmış ideal bir dünyada yaşadıklarını düşünürler. Böylece yazının tarihsel yönünü unutarak her dönem için geçerli bir yazı tarzı ya da üslup olduğunu düşünürler.

"Artık XVII. yüzyıldaki gibi yazmayışımız, [Fransız şair Jean] Racine [1639-1699] ile [Fransız asker, hedonist, edebiyat eleştirmeni Charles de] Saint-Evremond'un [1613-1703] kullandığ dilin lokomotiflerden ya da işçi sınıfından söz etmeye yatkın olmayışındandır. Şimdi, belki de arı dilden yana olanlar bize lokomotifleri yazmayı yasaklayacaktır. Ama sanat hiçbir zaman arı dilcilerden yana olmamıştır." ${ }^{00}$

Sözcüklerin binlerce yıldır artarak gelen şiirsel bir yükü vardır. Yirminci yüzyılda sözcükleri şiirsel yüklerinden arındırma işlemleri yoğun şekilde görülür. Oysa "şiirsel sözcük küçük bir

55 Jean-Paul Sartre, Çă̆ımızın Gerçekleri. Çeviren Sabahattin Eyuboğlu-Vedat Günyol. (İstanbul: Can Yayını, 1961). 113.

56 Sartre, Edebiyat Nedir?, 32.

57 Sartre, Edebiyat Nedir?, 32.

58 Sartre, Edebiyat Nedir?, 33.

59 Sartre, Edebiyat Nedir?, 35.

60 Sartre, Edebiyat Nedir?, 36. 
evrendir. Yüzyılın başlarındaki dil bunalımı, şiirsel bir bunalımdır.”' Sanat alanında bu tür çabalar yeni değildir. Örneğin Platon, Augustinus ya da Kant ve birçok filozof yazar, tüm zamanlar için geçerli olacak şekilde yazmak istediler. Fakat böyle olamadılar. Bu tür düşünür ve yazarlar, saf bir sanat anlayışından yanaydılar. Sartre bu tutumu "estetik saflık" ${ }^{62}$ olarak adlandırır. Bu tür filozoflar, yazarlar ve okuyucuların çoğunluğu nekforildir. Ölü sevicisidir. Sanatın içinde yer aldığı bu durum, Sartre’a göre onun "toplumsal bir görev" ${ }^{63}$ üstlenmiş olmasından kaynaklanır. Dava gütmeyen, sorumsuz ya da bağlı olmayan bir edebiyat, okuru saflaştırarak edebiyatı kamunun gözünde "boş laf” a indirger. Bu, modern estetik deneyimin sanat deneyiminin "saygılı bir uzaklık" tan seyretme "kayıtsızlık" ve "tarafsızlık" ${ }^{4}$ ilkeleridir. Sartre bu düşünceye karşı şöyle der: "Siz soyut sanat kavramınız adına ileri sürüyorsunuz şu hiç gerçekleşmemiş şeyin olasılığını; oysa ben, herkesin kabul ettiği bir olgu için bir açılama öne sürmekle yetiniyorum." ${ }^{65}$

Sonuç olarak, yazar yapıtını her durumda özgürlüğe sunmalıdır, çünkü okuyucu yazarın özgürlüğünü görmek ister. Böylece yazma eyleminin etik ve siyasi bir boyutu olduğu açıtır. Bunun doğruluğu insanın özgürlük tarihinin yazının gelişimiyle paralellik taşımasında görülebilir. Sorumluluk ya da bağlanılan dava burada saptanabilir. Yazı sanatının tarihinde bir eylem olarak yazmanın insanın özgürleşme süreciyle bağı gözlemlenebilir. Edebiyat Nedir? (1947) adlı yapıtında Sartre şöyle diyor:

"Düzyazı sanatı, düzyazının anlam taşıdığı biricik [toplumsal] yönetim biçimi olan demokrasi ile bağdaşır ancak. Biri tehlikedeyse, öteki de öyledir. [...] Böylece, hangi yoldan gelmiş olursanız olun, savunduğunuz görüşler ne olursa olsun, edebiyat sizi kavganın ortasına atıverir; yazmak, özgürlük isteminin bir biçimidir; bir kez yazmaya başladınız mı, ister istemez bağlanmışsınızdır." ${ }^{6}$

\section{Sonuç}

Sonuç olarak, varoluşçuluk insanı, onun bir doğası olduğunu düşünenlerden daha derin kavrar. İnsanın varlığı, onun kendi içinde ya da kendisi dışında hiçbir şeye dayanamaz. Varoluşçuluğun ilk ilkesini Sartre böylece belirler: "İnsan onun kendisini yaptığı şeyden başka bir şey değildir." ${ }^{67}$ Doğuştan ya da a priori bir doğru, iyi ve güzel yoktur, çünkü onu düşünecek mükemmel bir bilinç yoktur. Biz yalnızca insanların olduğu bir düzlem üzerindeyiz. Fransız şair Francis Ponge’un (1899-1988) dediği gibi: "İnsan insanın geleceğidir." ${ }_{68}$ Başka bir deyişle, bir kimse şöyle söylemelidir: "Ben benim geleceğimim.” Birbirimize şöyle demeyi denemeliyiz: "Sen özgürsün [...] Hiçbir genel ahlak kuralı sana ne yapacağını gösteremez. Bu dünyada bu konuda hiçbir işaret lutfedilmemiştir." ${ }^{99} \mathrm{O}$ halde, Sartre'dan edinebileceğimiz öneri şudur: Eylemlerde

61 Sartre, What is Literature?, 8.

62 "aesthetic purism", Sartre, What is Literature?, 17.

63 Sartre, Edebiyat Nedir?, 28.

64 Sartre, What is Literature?, 22.

65 Sartre, Edebiyat Nedir?, 73.

66 Sartre, What is Literature?, 75.

67 Sartre, Existentialism and Humanism, 28.

68 Sartre, Existentialism and Humanism, 34.

69 Sartre, Existentialism and Humanism, 38. 
bulunun! Fakat eylemlerinizden sorumlu olduğunuzu unutmayın. Eylemlerinizi eleştirin ve sonra daha başka eylemlerde bulunun.

Finansal Destek: Yazarlar bu çalışma için finansal destek almamışlardır.

\section{Kaynakça}

Genet, Jean. Giacometti’nin Atölyesi. Çeviren Hür Yumer. İstanbul: Metis Yayınları, 2007.

Jonson, H. W. History of Art, Vol. I. Fourth Edition, revised and expanded by Anthony Janson. New York: Abrams, 1991.

Heidegger, Martin. Varlık ve Zaman. Çeviren Kaan Ökten. İstanbul: ALFA, 2018.

Husserl, Edmund. "Fenomenoloji", çeviren Aydın Gelmez. Baykuş, Felsefe Yazıları Dergisi, 6 (2010): 29-47.

Kant, Immanuel. Yargı Yetisinin Eleştirisi/Kritik der Urteilskraft. Çeviren Aziz Yardımlı. İstanbul: İdea Yayınevi, 2006.

Platon. Devlet. Çeviren Sabahattin Eyüboğlu ve M. Ali Cimcoz. İstanbul: Remzi Kitabevi, 1988.

Sartre, Jean-Paul. The Psychology of Imagination. Translated by Bernard Frechtman, New York: Philosophical Library, 1948.

Sartre, Jean-Paul. Çağımızın Gerçekleri. Çeviren Sabahattin Eyuboğlu-Vedat Günyol. İstanbul: Can Yayını, 1961.

Sartre, Jean-Paul. Nausea. Translated by Robert Baldick. London: Penguin, 1965.

Sartre, Jean-Paul. Existentialism and Humanism. Translation and introduction by Philip Mairet. London: Methuen \& Co. LTD., 1966.

Sartre, Jean-Paul. No Exit, and Three Plays. ( "No Exit", "The Flies." Translated by S. Gilbert. "Dirty Hands", "The Respectful Prostitute." Translated by I. Abel). New York: Vintage International Edition, 1989.

Sartre, Jean-Paul. Being and Nothingness, A Phenomenological Essay on Ontology. Translation and introduction by Hazel E. Barnes. New York: Washington Square Press, 1992.

Sartre, Jean-Paul. Estetik Üstüne Denemeler. Çeviren Mehmet Yılmaz. Ankara: Doruk Yayımcılık, 1999.

Sartre, Jean-Paul. What is Literature? Translated by Bernard Frechman, with an introduction by David Caute. London and New York: Routledge, 2001.

Sartre, Jean-Paul. Being and Nothingness, An essay on phenomenological ontology. Translated by Hazel E. Barnes. Intdoduction by Mary Warnock, with a new preface by Richard Eyre. London and New York: Routledge, 2003.

Sartre, Jean-Paul. Edebiyat Nedir? Çeviren Bertan Onaran. İstanbul: Can Yayınları, 2008.

Sartre, Jean-Paul. Bulantı. Çeviren Selâhattin Hilâv. İstanbul: Can Yayınları, 2009.

Satre, Jean-Paul. Toplu Oyunlar, Gizli Oturum, Mezarszz Ölüler, Sinekler, Kirli Eller, Şeytan ve Yüce Tanr, Saygılı Yosma. Çeviren Işık M. Noyan. İstanbul: İthaki Yayınları, 2009a.

Sartre, Jean-Paul. Varlık ve Hiçlik. Çeviren Turhan Ilgaz ve Gaye Çankaya Eksen. İstanbul: İthaki, 2010.

Sartre, Jean-Paul. The Imaginary, A Phenomenological Psychology of the Imagination, with introduction by Arlette Eelkaim-Sartre and Jonathan Webber. London: Routledge, 2010a. 
